\title{
ARTIGOS
}

\section{POLYCYSTIC HYDATID DISEASE IN BRAZIL. REPORT OF FIVE NEW HUMAN CASES AND A SHORT REVIEW OF OTHER PUBLISHED OBSERVATIONS}

\author{
A. D'Alessandro, M.A.P. Moraes and A.N. Raick
}

\begin{abstract}
This paper describes five additional Brazilian buman cases of polycystic bydatid disease due to Echinococcus vogeli, reviews the previous cases reported in Brazil, including one report of $\mathrm{E}$. oligarthus (20 in total), and some epidemiological aspects of this disease which is no longer a curiosity but ratber a problem that is not medically easy to bandle. Its presence sbould be expected in any miral area of the New World where bumans bave not eliminated wild felids/canids, bush dogs, pacas, agoutis and otber wild rodents.
\end{abstract}

Key-words: Polycystic bydatid disease. Echinococcus vogeli. Brazil.

Ecbinococcus granulosus is known to be endemic in humans, ungulates and domestic dogs in Uruguay, Argentina, Chile, the Andean zone of Peru and Rio Grande do Sul, Brazil. However, the parasite probably is present in every country in the continental Americas ${ }^{5}$, but sporadic human cases are rare or seen in immigrants from endemic areas of the same or another country. The reason for this is not clear, but it may be due to epidemiological circumstances that prevent transmission, or to the behavior of the strain of the parasite present in non-endemic areas.

In addition, hydatids showing a polycystic morphology, rather than unilocular, had been observed in humans and animals and were cataloged as alveolar, multicystic or multilocular hydatids and interpreted as due to E. granulosus, E. multilocularis (cycle canidsmall rodent, in the arctic zones) or more recently to $E$. oligartbrus (wild cat-agouti cycle, mostly in tropical areas). However, these diagnoses were not substantiated by experimental infections in carnivores to obtain the adult worms which are easy to differentiate.

Department of Tropical Medicine,Tulane University School of Public Health and Tropical Medicine, New Orleans, LA, USA, Fundação Serviços de Saúde Pública, Ministério de Saúde, Belém, PA and Departamento de Patologia, Universidade de Brasilia, Brasilia, DF, Brasil.

Address to: Dr. A. D'Alessandro. Department of Tropical Medicine, Tulane University School of Public Health and Tropical Medicine, 1501 Canal Street, New Orleans, LA 70112, USA. Fax: 504 587-7313.

Recebido para publicação em 20/06/95.
Fortunately, while working in Colombia, we were able to infect dogs and cats with polycystic hydatid metacestodes of human and animal origin and demonstrated the presence in the country of the two neotropical Echinococcus species E. oligartbus and E. vogeli (Ev). We described the larval characteristics of $\mathrm{Ev}$, also polycystic, in the only important known host, the paca (Cuniculus paca). The adult parasite had been described by Rausch and Bernstein ${ }^{26}$ in a bush dog (Speotbos venaticus) from Ecuador and, as they had predicted due to the food habits of the bush dog, the intermediate host was found to be the paca.

As mentioned above, experimental infections demonstrated that the metacestodes of the two neotropical species were both polycystic. The differential morphological characteristics were studied and described. It was found that the shape, the relative proportion of handle and guard/blade and the size of the hooklets of the protoscolices were of particular importance ${ }^{782829}$.

Since the original description of polycystic hydatid disease (PHD) in 1979 involving 13 cases in 4 countries, no less than 63 human cases due to Ev (and also $\boldsymbol{E}$. oligarthus) have been found in 10 countries, including Brazil.

This paper describes the information available (mostly pathological) on 5 additional Brazilian human cases of polycystic hydatid disease (PHD) and discusses the other cases reported in Brazil (Table 1), and some epidemiological aspects of this interesting disease which is no longer a curiosity but rather a problem not medically easy to handle. 
D'Alessandro A, Moraes MAP, Raick AN. Polycystic bydatid disease in Brazil. Report of five new buman cases and a sbort review of otber published observations. Revista da Sociedade Brasileira de Medicina Tropical 29:219-228, mai-jun, 1996.

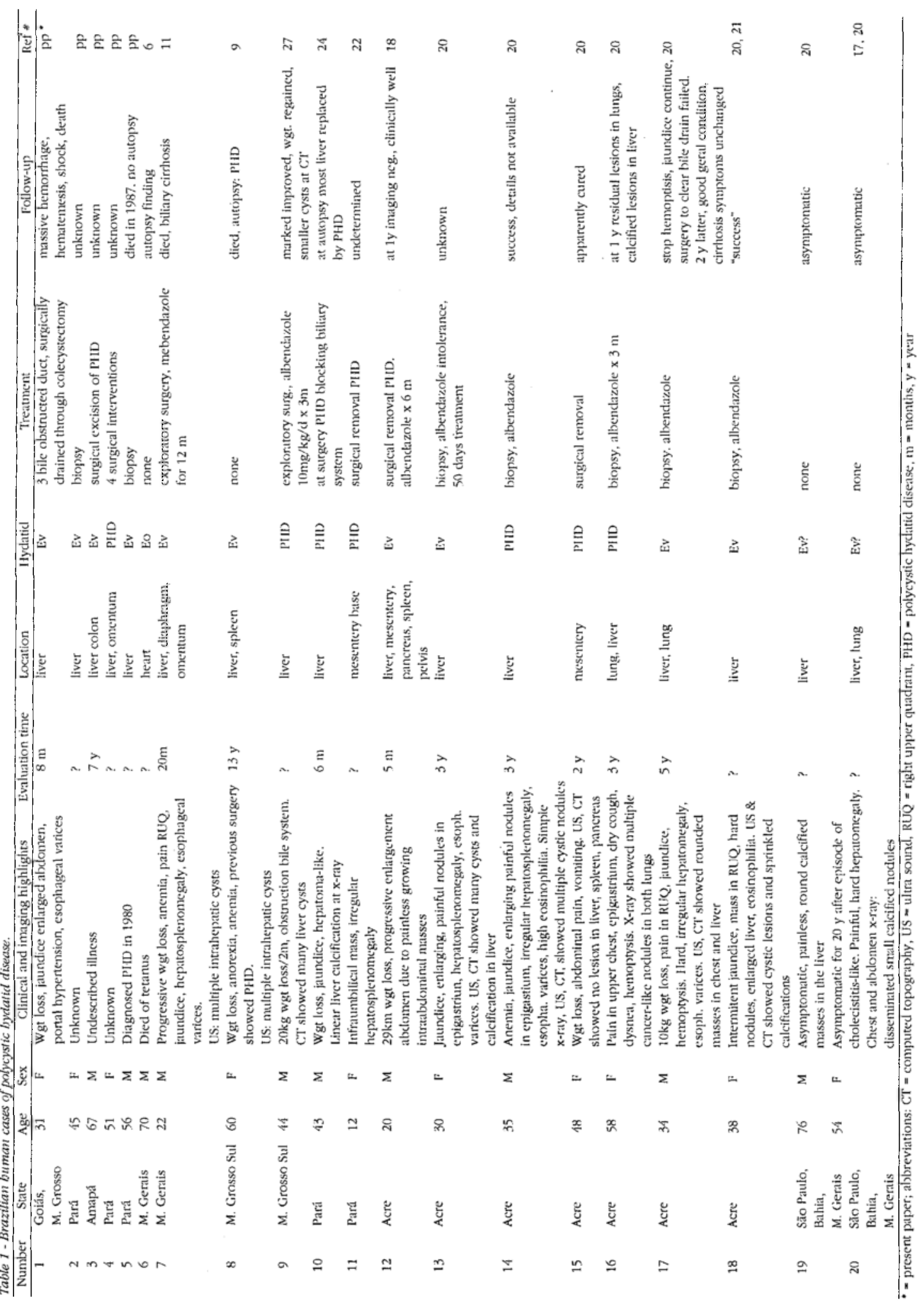


D'Alessandro A, Moraes MAP, Raick AN. Polycystic bydatid disease in Brazil. Report of five new buman cases and a sbort retieu of other published observations. Revista da Sociedade Brasileira de Medicina Tropical 29:219-228, mai-junl, 1996.

Polycystic bydatid infections in Brazilian animals. Brumpt and Joyeux ${ }^{2}$ found in the liver and spleen of 1 of 4 agoutis (Dasyprocta agouti $=D$. leporina) collected in Alburquerque, Lins, State of Sao Paulo, a polycystic hydatid that they described as the metacestode of a new species of Echinococcus: E. cruzi rather than $E$. oligartbrus. Based on a careful study of the differential characteristics of the 2 neotropical species, Ev and E. oligarthrus, from different origins and the original slides of $E$. cruzi, it was arrived to the conclusion that the rostellar hooklets from protoscolices of E. oligartbrus and $E$. cruzi corresponded in form, although those from the latter were slightly greater in length. The difference was considered of no taxonomic significance and therefore they placed $E$. cruzi in synonymy with $E$. oligarthrus ${ }^{26}$

The occurrence of the larval stage of Ecbinococcus spp in the Americas by species of host and country were summarized ${ }^{8}$. In Brazil, other metacestodes collected in agoutis near Belem were also found to be $E$. oligartbrus but the report of E. granulosus in a Brazilian agouti by Lutz lacks sufficient information to allow a definitive taxonomic opinion. In addition to these observations, $E$. oligartbrus has been reported in various countries and in a few species of mammals; Proechimys spp. (spiny rat), and once in Cuniculus paca, and in Didelphis marsupialis (opossum). More recently Ev was found in Sylvilagus floridanus (wild rabbit) from Venezuela ${ }^{16}$ and in pacas from Para State (Moraes, this report); in Acre State ${ }^{21}$; in Bolivia ${ }^{12}$ and in Ecuador ${ }^{14}$.

The carnivores reported naturally infected with $E$. oligarthrus are the following wild cats: Felis yagouaroundi, $F$. concolor, $F$. onca, $F$. pardalis, $F$. geoffroyi and $F$. colocolo ${ }^{8}$; several of these cats have extensive geographic ranges. The widest is that of the cougart, Felis concolor, which occurs in northen British Columbia, Canada, and southward to Tierra del Fuego. Some, such as the ocelot and the jaguar, which formely were present in SW the US seem to have disappeared from this country. On the contrary, the bush dog, Speotbos venaticus (Figure 1), distributed from Panama to northen Argentina, and the domestic dog, are the only animals that have been reported naturally infected with Ev and the paca is the only important intermediate hosts (Figure 2).

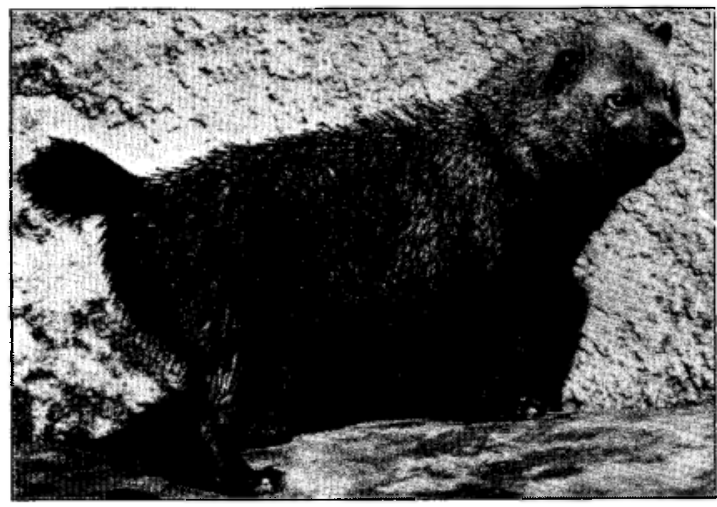

Figure 1 - Bush dog, Speothos venaticus. Photo courtesy of the Los Angeles Zoo.

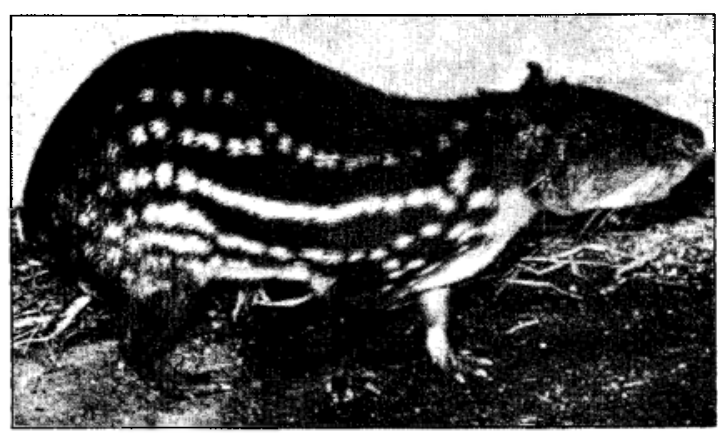

Figure 2 - Adult paca, Cuniculus paca. Photo courtesy of Dr. Ignacio Borrero, Universidad ael Valle, Cali, Colombia.

It should be mentioned that PHD transmission has been reported in zoos where bush dogs served as a sourse of infection for nutrias, Myocastor coypus ${ }^{29}$, and a group of primates: gorillas, orangutans and chimpanzees ${ }^{15}$ 23. This information should be useful to alert zoo veterinarians to detect infections in captive bush dogs, using antiparasitic drugs to recover the adult worms and in primates, using ultrasound procedures to detect the metacestodes.

Diagnosis. It seems pertinent in this short review to mention how the diagnosis of PHD is carried out in humans.

1. Demonstration of polycystic masses by physical examination or by using imaging 
D'Alessandro A, Moraes MAP, Raick AN. Polycystic bydatid disease in Brazil. Report of five new buman cases and a sbort review of other published observations. Revista da Sociedade Brasileira de Medicina Tropical 29:219-228, mai-jun, 1996.

procedures: $\mathrm{x}$ ray, showing polycystic tumors, usually with some calcifications $2-3 \mathrm{~cm}$ or more in diameter with irregular borders, but they may have diverse forms and configurations. Ultrasound, CT and MRI are more sophisticated and expensive procedures but useful for diagnosis ${ }^{122}$. The metacestode is usually present simultaneously in various organs of the upper and lower abdomen, the chest, and the orbit (D'Alessandro, unpublished).

2. The patient lives or has lived in rural areas with abundant wild life, and usually is familiar with pacas.

3. Serological tests. IHA and Immunoblot usually are positive in cases diagnosed by other means. Very recently, Gottstein et al $1995^{13}$ have obtained a purified Ev antigen, $\mathrm{Ev} 2$, allowing discrimination of nonEchinococcus infections and E. granulosus infections from Ev. Only some alveolar hydatid cases could not be discriminated. However, the distribution of E. multilocularis is holartic rather than neotropical so its distribution does not overlap in these regions.

4. Parasitological characteristics of PHD obtained by biopsy, pathological specimens or necropsy: a) the shape, proportions of the parts of the protoscolex hooklets (better seen in squash preparations) and b) the morphology of the body or walls of the hydatid in tissue sections stained with $\mathrm{H} \& \mathrm{E}$ and $\mathrm{PAS}^{629}$.

\section{Case Reports}

Case 1. (MVS (A93-87). A 31-year-old Brazilian female agricultural worker, born in Goias State but living in Mato Grosso at the time of presentation, was admitted to the teaching hospital of Brasilia in October 1987 complaining of an enlarged abdomen, diarrhea, increasing jaundice, and generalized itching since a few months. She had been diagnosed as having viral hepatitis one month earlier in another hospital. At admission she was found to be in poor general health, with a history of a $12 \mathrm{~kg}$ weight loss during the previous weeks. She was markedly jaundiced, and the physical exam revealed palmar erythema and signs of generalized skin lesions due to scratching. The abdomen was distended and the liver was hard and palpable
$20 \mathrm{~cm}$ below the right costal margin. No ascites or abdominal collateral circulation were detected. Main laboratory findings at admission included: total bilirubin, $33 \mathrm{mg} / \mathrm{dl}$ with the direct fraction of $21 \mathrm{mg} / \mathrm{dl}$; alkaline phosphatase, 57U; AST 36U; ALT 40U; total protein $6.8 \mathrm{gr} / \mathrm{dl}$, albumin $3.2 \mathrm{gr} / \mathrm{dl}$; creatinine $0.7 / \mathrm{dl}$. The WBC count was normal but $11 \%$ eosinophils was reported. The abdomen ultrasound showed enlarged liver and spleen with a cavernous mass in the porta hepatis, dilated intrahepatic bile ducts, signs of portal thrombosis, and a calcified nodule in the liver $(2 \mathrm{~cm} \times 2 \mathrm{~cm})$. With the diagnosis of obstructive jaundice and portal hypertension, an exploratory laparotomy was carried out one month after admission. Examination of the porta hepatis showed enlarged, recanalized umbilical veins. The gallbladder appeared shriveled and without calculi. When the common bile duct was opened, multiple small vesicles were seen (Figure 3). An intraoperative cholangiogram revealed the left hepatic bile duct to be obstructed. The right

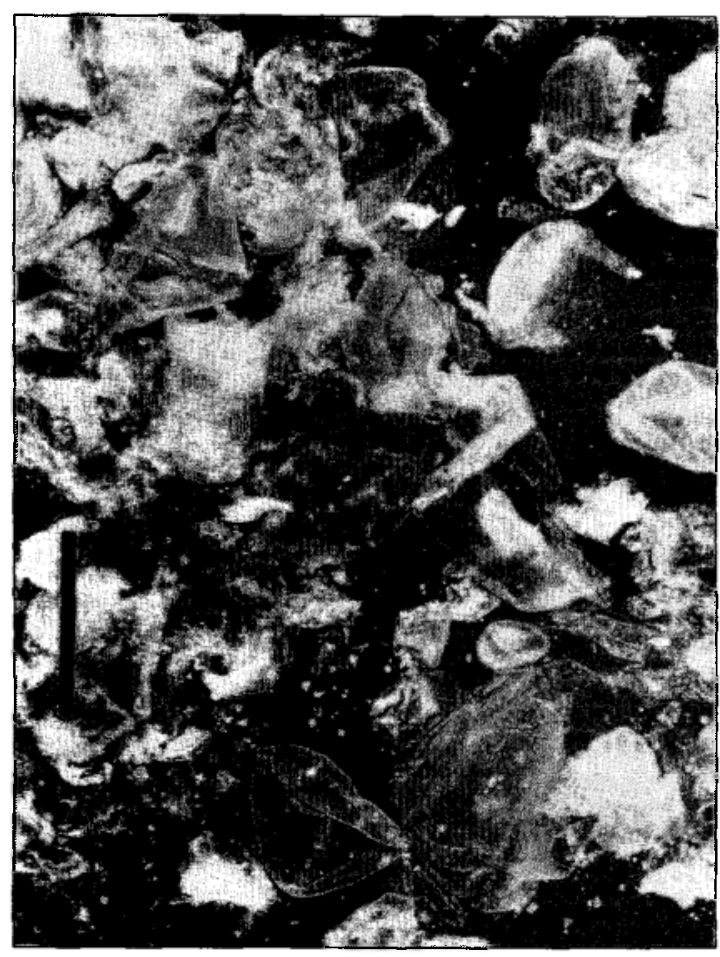

Figure 3 -Echinococcus vogeli cyst obtained from the liver and the biliary drain of case 1. Note the diversity of size and the presence of brood capsules, free and within the cysts. Bar $=1 \mathrm{~cm}$. 
D'Alessandro A, Moraes MAP, Raick AN. Polycystic bydatid disease in Brazil. Report of five new buman cases and a sbort review of other published observations. Revista da Sociedade Brasileira de Medicina Tropical 29:219-228, mai-jun, 1996.

hepatic bile duct was impermeable and the cystic duct was fibrotic. A cholecystectomy was performed and external drainage of the biliary system was established. Two days following surgery an episode of bleeding from the surgical excision and the externalized drain was observed, and fluid from the drain contained parasitic cysts. Two weeks after surgery the patient experienced massive hematemesis, hypovolemic shock, and died the following day. At autopsy numerous vesicles were observed on the surface and in sections of the parenchyma and the porta hepatis of the liver (Figure 4). The parasite was alive in some areas and dead in others. The

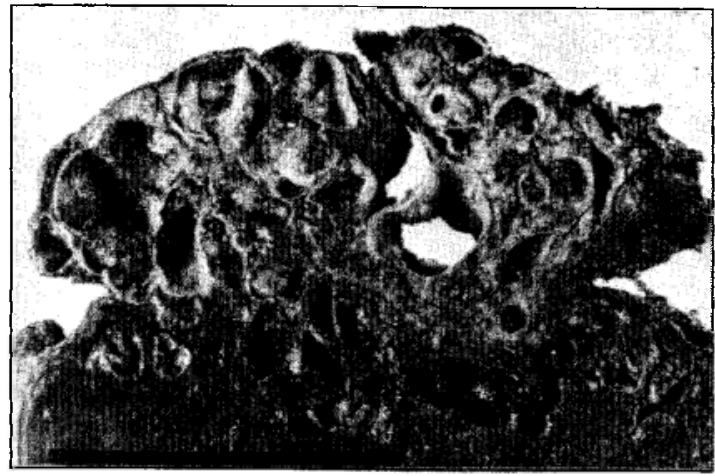

Figure 4 -Echinococcus vogeli shown in a liver section of case 1. The polycystic appearance of the lesion can be clearly seen as well as the invasion of the parencbyma by the metacestode. Bar $=20 \mathrm{~cm}$

laminated membrane was thick and the germinal thin, showing few calcareous corpuscles. Brood capsules and protoscolices with typical Ev hooklets were frequently seen. (Figure 5 and 6 ). Between the host fibrous tissue reaction and the parasite, an accumulation of granular material representing dead eosinophils was frequently seen. In several areas proliferation of the laminated membrane was evident,at times having a cerebroid appearance. In some protoescolices several abnormal looking hooklets were seen (Figure 7)

Case 2. (OAF, Brasilia University, BU29023) Year 1976. A 45 year-old female from Curralinho, rural area of Para State, with no clinical history available. A liver biopsy contained a polycystic hydatid with a laminated membrane showing a cerebroid appearance (Figure 8). The parasite was

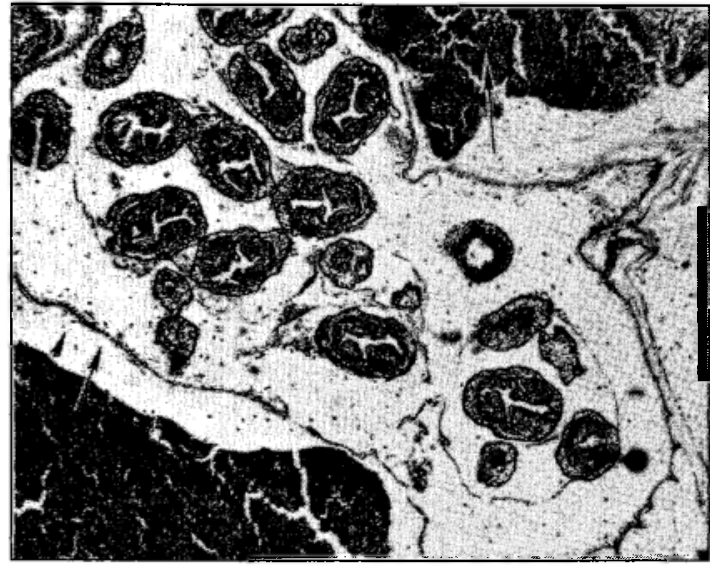

Figure 5 - Tissue section ( $H \& E$ ) of Echinococcus vogeli of case 1. Thick laminated membrane (arrowbead), thin germinal membrane (medium length arrow), granular material between the laminated membrane ana the liver (long length arrow), brood capsules and protoscolices. Bar $=200 \mu \mathrm{m}$.

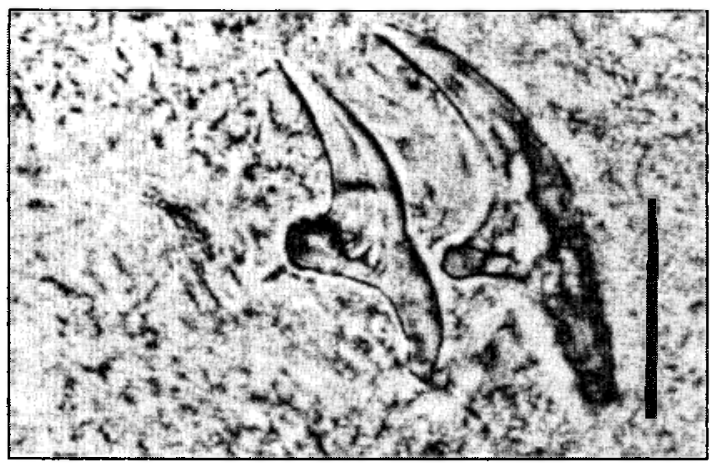

Figure 6 - Unstained squash preparation of fixed protoscolices of case 1 , sbowing large and small booklets of E. vogeli. Bar $=20 \mu \mathrm{m}$.

mostly dead and surrounded by histiocytes arranged in a palisade fashion. Protoscolices and hooklets conformed to those of Ev.

Case 3. ( DMB, BU- 28000). Year 1976. A 67 year-old male from Macapa, Amapa State. Tumors of the liver and of colon were excised after 7 years of illness. The metacestode was dead but it showed Ev hooklets and proliferating, cerebroid laminated membrane.

Case 4. ( MSS, BU-13539). Year 1971. A 51 year-old female from Moju, Para State, underwent surgery 4 times, 3 of which antedated 1971. During the first surgery, 
D'Alessandro A, Moraes MAP, Raick AN. Polycystic bydatid disease in Brazil. Report of five new buman cases and a short review of other published observations. Revista da Sociedade Brasileira de Medicina Tropical 29:219-228, mai-jun, 1996.

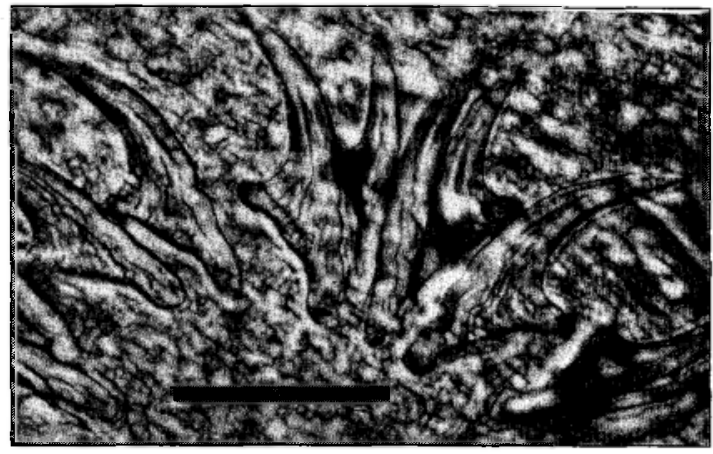

Figure 7 - Unstained squash preparation of fixed protoscolices of case 1 , showing normal and abnormal booklets (arrows) of E. vogeli. Bar $=20 \mathrm{um}$.

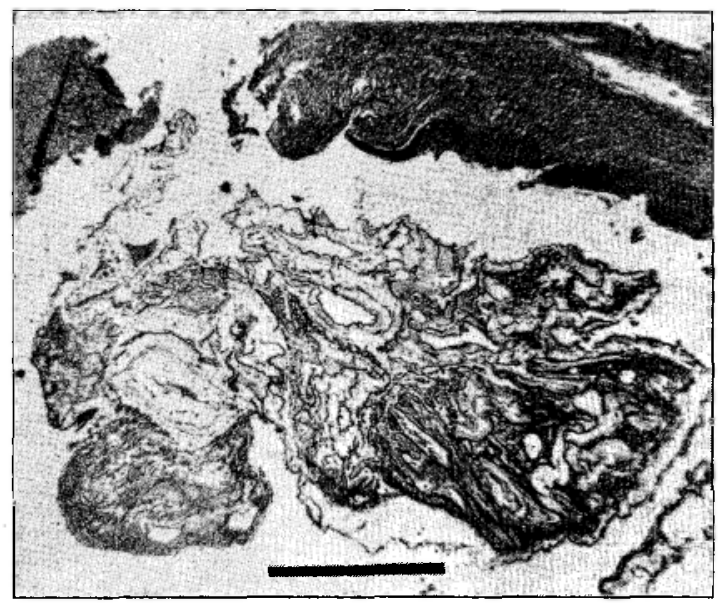

Figure 8 - Tissue section ( $H \& E$ E). Convoluted laninated membrane within the lumen of a cyst (case 3) given the appearence of a cerebroid formation. Bar $=20 \mathrm{um}$.

polycystic lesions from the liver and omentum were removed. This is the only information that was obtained.

Case 5. (BSR, studied by Mario Moraes in 1987). A 56 year-old agricultural worker from Paragominas, Para State. In 1980 he had been told that he was infected with hydatid disease. The patient died in 1987 and an autopsy could not be performed. However, specimens available from previous biopsies showed he was infected with polycystic hydatids with a laminated membrane showing a cerebroid appearance. Protoscolices and $\mathrm{Ev}$ hooklets were seen. This patient had brought with him an Ev-infected paca to demonstrate the parasitic lesions of the animal.

In summary, five new cases of PHD are reported. In 4 the characteristics of the metacestode and, in particular, the protoscolices' hooklets indicate that the infection was due to $\mathrm{Ev}$. The first patient died of complications after surgery carried out to allow the bile to drain. Little clinical information was available from the other 4 cases except that the illness that originated the surgery to make a diagnosis demonstrated that it was a PHD and that the parasite involved in at least 3 cases was Ev due to the morphology of the hooklets. Whether the cerebroid appearance of the laminated membrane of the 4th case is sufficient to indicate that it is due to $\mathrm{Ev}$ is a point that should be confirmed by the study of more $E$. oligartbrus in humans.

A summary of the data of the new and previously reported human cases in Brazil is presented in Table 1.

\section{DISCUSSION}

As stated earlier, it is understandable that PHD was not diagnosed until recently. Ev was described in $1972^{26}$ in the bush dog, but the metacestode was not recognized until the observations made with Colombian material ${ }^{22}$. With the differential criteria established, it became possible to recognize that Eo was the origin of an Echinococcus heart infection found outside the endemic area of $E$. granulosus in Brazil ${ }^{4}$. Also that cases 2 and 3 in the present report, recognized in 1976 as polycystic and therefore not due to $E$. granulosus, were not published by Moraes up until now, in the present report. They were both Ev. Reports of all Brazilian cases, including those presented in congresses (as new, overlooked, or previously unreported), are summarized in Table 1.

So far, in Brazil, there have been 20 PHD cases reported, 9 males and 11 females; the mean age was 41 with a range of 12 to 76 years. Only 7 were younger than 30 . Three cases were asymptomatic individuals; 2 with groups of rounded calcifications in the liver and lung (considered probably dead and calcified metacestodes of PHD) and the patient with $E$. oligartbrus in the heart, who died of tetanus and at autopsy showed this parasite as an accidental finding 
D'Alessandro A, Moraes MAP, Raick AN. Polycystic bydatid disease in Brazil. Report of five new buman cases and a short review of otber publisbed observations. Revista da Sociedade Brasileira de Medicina Tropical 29:219-228, mai-jun, 1996.

The location of the parasites was: liver alone ( 9 cases), liver and lung ( 5 cases), base of the mesentery ( 1 case) and cysts in the liver and other organs in the last 4 . Five of these 20 cases died as a consequence of the PHD which had caused liver cirrhosis, obstructive jaundice, portal hypertension and or esophageal varices.

Of the 20 cases, 11 were definitely due to Ev and one to E. oligarthrus because the typical characteristics of the hooklets; in 7 , however, hooklets were not seen and in 2 there were no pathological specimens available for microscopic examination (only radiological). Although the typical characteristics of the $E$. oligarthrus metacestode is well established, only one case of a dead $E$. oligartbrus in a man's heart has been described showing not only hooklets but its cystic appearance, not different from that shown in animals.

It is clear that $\mathrm{Ev}$ is found much more frequently in humans than is E. oligarthrus. The former is transmitted from the domestic dog, which is a good host for Ev but not for E. oligarthrus; so far as has been observed, the latter develops to sexual maturity and produces eggs only in wild cats (Felidae) of various species ${ }^{8}$

Fortunately, most of the Brazilian investigators have been aware of the studies of PHD, and have recognized its presence in Brazil. In 1992 it was found an endemic area of human transmission in Acre State ${ }^{22}$. The patients were thoroughly studied and longitudinal observations made possible the evaluation of beneficial response to albendazole treatment in 4 of 6 patients ${ }^{20}$. On the other hand, 1 year of mebendazole treatment was inefficient to avoid the death of one patient who had long lasting lesions in the liver with obstruction of the biliary system and portal hypertension ${ }^{11}$. The same failure was observed in two of the Meneghelli patients treated with albendazole ${ }^{20}$.

Surgical treatment was effective in removing the metacestode from the base of the mesenterium and the patient was reported cured (case 4 of Meneghelli) ${ }^{21}$. In 5 of the 20 Brazilian PHD cases, their fate was unreported. In our experience and in the study of the results reported by others, surgical treatment should be recommended when the metacestode is small, localized and has not responded to medical treatment. Radical cures may be expected in these cases, but probably not when the PHD involves a large portion of the liver or other organs. However, more observations for prolonged periods of time are necessary to assess the chances of permanent improvement or cure in each case.

When the biliary system is involved, or cirrhosis has developed with splenomegaly and esophageal varices, surgery has accelerated the death of the patient due to complications. However, if the itching due to the jaundice is very troublesome, drainage of the biliary tract is usually required.

Surgery has been used successfully as a palliative mean of diminishing the effects of large numbers of cysts, which interfere with normal physiological activity of the stomach and other organs, by removing as many cysts from the mesenteries or those emerging from organs as possible. In addition, the absence of intraperitoneal masses allows the patient to sleep more confortably (D'Alessandro, umpublished).

In summary, medical treatment with albendazole has been used with good results although really it is too early to assess long lasting cures. However, albendazole should be used and evaluated on the patient's well being. In general, Ev seems to be less aggressive than E. multilocularis and we know of asymptomatic patients who had the infection for several decades.

The epidemiological information obtained from the Brazilian cases is valuable. The Acre patients not only were familiar with pacas but also had seen parasitic vesicles in their abdomen. As in Colombia, the viscera of the pacas are fed to dogs. The conditions in Acre, at least, seem favorable for studies of transmission of $\mathrm{Ev}$ due to the number of infected persons reported and unreported ${ }^{20}$. In this place it has not been established how the pacas get the infection, but Acre is within the geographical distribution of the bush dog. In $1986^{\circ}$ it was reported 13 specific places were the bush dog had been sen in Brasil including the states of Minas Gerais, Mato Grosso, Santa Catalina and São Paulo, and these places were shown in a map (Figure 9). Also unknown is the frequency of infection in pacas, in domestic dogs and in humans (which could be assessed by using the latest available serological tests). 
D'Alessandro A, Moraes MAP, Raick AN. Polycystic bydatid disease in Brazil. Report of five new buman cases and a short review of other published observations. Revista da Sociedade Brasileira de Medicina Tropical 29:219-228, mai-jun, 1996.

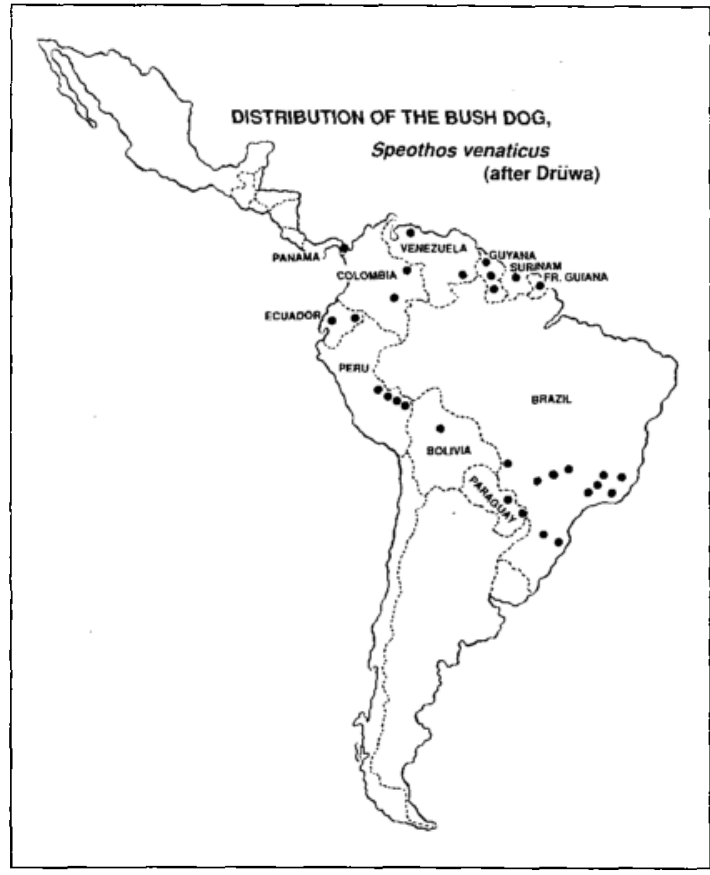

Figure 9 - Map 1 showing the distribution ob the bush dog, Speothos venaticus. From Peter Druwa, reference 9 . Courtesy of the author and the Editor of the journal.

In Colombia, people from the enzootic area could not provide information on the presence of the bush dog until a photo of the animal was presented. Then most people recognized the animal. The local name in the Colombian Oriental plains is "zorro guache" and in Brazil the local name is "cachorro do mato vinagre"

A survey of a limited random sample of adult pacas (weighing more than 10kg) should be sufficient to assess the prevalence of $\mathrm{Ev}$ infection, considering that the frequency in Colombia was $30 \%$ in adult animals, $16 \%$ in subadults and none in the juveniles weighing less than $5.5 \mathrm{~kg}^{8}$.

Although Ev infects humans and animals more frequently than $E$. oligartbrus the geographical distribution of wild cats is wider than that of the bush dogs. Therefore, the presence of PHD outside the range of the bush dog may be due to $E$. oligarthrus. However, it has been postulated that animals other than the bush dog and pacas may be involved in the transmission of $\mathbf{E v}^{6}$.

Actually, both passibilities may play a role. To answer this question the collaboration of

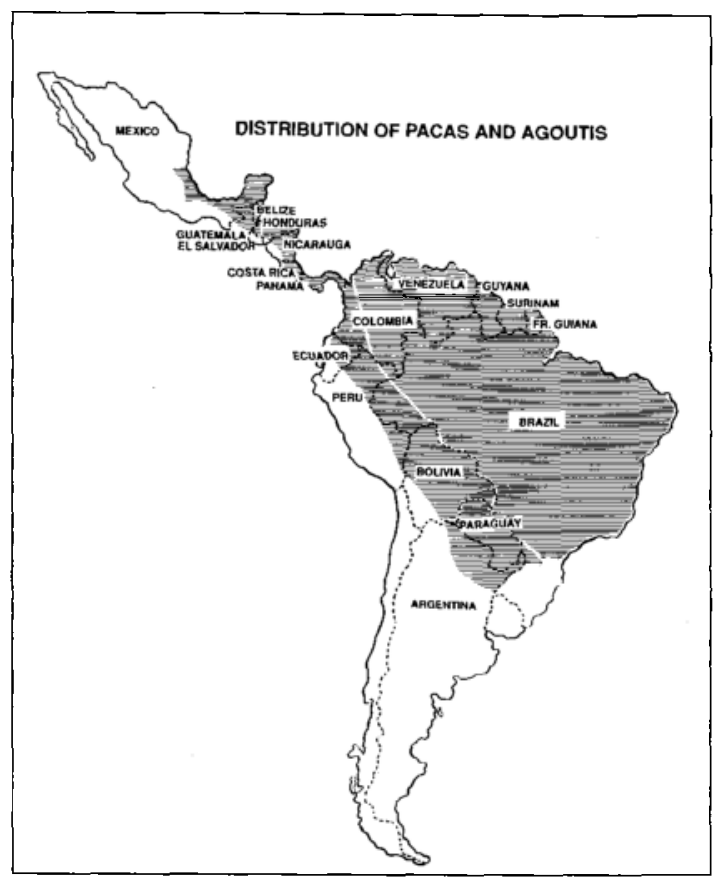

Figure 10 - Map 2 showing the distribution of pacas, Cuniculus paca and agoutis, Dasyprocta $s p p$, from different sources.

zoos is required by the treatment with praziquantel of canids/felids that have been capture in the wild as well as those which has been in captivity, in particular for a short time. Long lasting captivity may have an effect on some parasites which are eliminated spontaneously.

It is important to determine the species involved in a case of PHD because, apparently, $\mathrm{Ev}$ is susceptible to medical treatment with albendazole although, as stated earlier, long term observations of reported successes require prolonged periods of observation. A number of reports are encouraging, at least in regard to the improvement of the patient's health.

\section{RESUMO}

Este trabalbo descreve cinco novos casos bumanos brasileiros de doença bidática policística, causada por Echinococcus vogeli e faz uma revisão de casos anteriores relatados no Brasil, incluindo um relato sobre $\mathrm{E}$. oligarthrus (num total de 20) $e$ alguns aspectos epidemiológicos desta doença, que já não é mais uma curiosidade mas, sem dúvida, 
D'Alessandro A, Moraes MAP, Raick AN. Polycystic hydatid disease in Brazil. Report of five new buman cases and a short review of other published observations. Revista da Sociedade Brasileira de Medicina Tropical 29:219-228, mai-jun, 1996.

um problema de dificil manejo do ponto de vista médico. Sua presença pode ocorrer em todas as áreas rurais do Novo Mundo, onde o bomem ainda nâo eleminou os felinos e caninos selvagens, cachorro do mato, paca, cutia e outros roedores selvagens.

Palavras-chaves: Doença hidática policística. Echinococcus vogeli. Brasil.

\section{ACKNOWLEDGMENTS}

We thank Dr. Robert L Rausch (Department of Comparative Medicine, University of Washington, Seattle, WA.) and Dr. M Dale Little (Department of Tropical Medicine, Tulane University School of Public Health and Tropical Medicine, New Orleans, LA.) for reviewing the manuscript and offering useful suggestions.

\section{REFERENCES}

1. Amunarriz M. Estudios sobre patalogias tropicales en la Amazonia Ecuatoriana. Vicariato Apostolico de Aguarico, Ed. CICAME, Pompeya, Napo, Region Amazonica Ecuatoriana. 1991

2. Brumpt E, Joyeux Ch. Decription d'un nouvel echinocoque: Ecbinococcus cruzi n.sp. Annales de Parasitologie Humaine et Comparee 2:226$231,1924$.

3. Cabrera A, Yepes J. Mamiferos Sul Americanos. Ediar editors. 2nd. edition, Buenos Aires, 1960.

4. Chapadeiro E, Lopes ER, Mesquita PM. Prymary hydatid cyst of the heart. Journal of Tropical Medicine 68:9-11,1965. Portugese version published in Revista do Instituto de Medicine Tropical de São Paulo 6:171-173, 1954.

5. D'Alessandro A, Henao $\mathrm{H}$, Cuello C. Un caso colombiano autoctono de hidatidosis poliquistica multiple de higado, pericardio, pulmones, pleura y corazon. Acta Medica del Valle 9:28-35, 1978.

6. D'Alessandro A, Ramirez LE, Chapadeiro E, Lopes E, Mesquita PM Second recorded case of human infection by Echinococcus oligarthrus. The American Journal of Tropical Medicine and Hygiene 52:29-33, 1995.

7. D'Alessandro A, Rausch RL, Cuello C, Aristizabal N. Echinococcus vogeli in man, with a review of polycystic hydatid disease in Colombia and neighboring countries. The American Journal of Tropical Medicine and Hygiene 28; 303-317, 1979.

8. D'Alessandro A, Rausch RL, Morales GA, Collet S, Angel D. Ecbinococcus infections in Colombian animals. The American Journal of Tropical Medicine and Hygiene 30:1263-1276, 1981.

9. Druwa P. Perro de grulleiro, der Sudamerikanische Wadhund-ein Ratsel fur die Hundeforschung. In Zeitschrift des Kolner Zoo 25:71-90, 1982.

10. Ferreira MS, Nishioka SA, Rocha A, D'Alessandro A. Echinococcus vogeli polycystic hydatid: report of two Brazilian cases outside the Amazon region. Transactions of the Royal Society of Tropical Medicine and Hygiene 89:286-287,1995.

11. Ferreira MS, Rocha A, Goncalves EG, Carvalho AM, Nishioka SA, Andrade NB. Um caso de hidatidose policística autóctona de Minas Gerais, Brasil. Revista da Sociedade Brasileira Medicina Tropical 20:181-186,1987

12.Gardner SL, Rausch RL, Camacho OCJ. Echinococcus vogeli Rausch and Bernstein, 1972, from the paca, Cuniculus paca L. (Rodentia: Dasyproctidae), in the Departamento de Santa Cruz, Bolivia. Journal Parasitology 74:399-402, 1988.

13.Gottstein B, D'Alessandro A, Rausch RL. Immunodiagnosis of polycystic hydatid disease/polycystic echinococcosis due to Echinococcus vogeli. The American Journal of Tropical Medicine and Hygiene 53:558-563, 1995.

14. Guderian R, Kerrigan KR, Chico ME, Guevara A, HidaIgo G. Hidatidosis humana en el oriente ecuatoriano: informe de los primeros dos casos. Revista Medica Vozandes 4:57-60, 1990.

15. Howard EB, Gendron AP. Echinococcus vogeli infection in higher primates at the Los Angeles Zoo. In: Montal RJ, Migaki G (eds) The comparative pathology of zoo animals. The symposia of the National Zoological Park. Smithonian Society. Washington, DC. Smithonian Institution Press 379-382, 1980.

16. Lopera RD, Melendez RD, Fernandez I, Sirit J, Perera MP. Orbital hydatid cyst of Echinococcus oligarthrus in a human in Venezuela. Journal Parasitology 75:467-470, 1989.

17.Melendez RD, Yepez MS, Coronado A. Echinococcus oligarthrus cysts of rabbits in Venezuela. Journal Parasitology 70:1004-1005, 1984.

18. Meneghelli UG. Calcificações hepáticas múltiplas decorrentes de doença hidática policística. Revista Goiana de Medicina 31: 53-60, 1985.

19. Meneghelli UG, Barbo MLP, Magro JE, Bellucci AD, Llorach Velludo MAS. Polycystic hydatid disease (Ecbinococcus vogeli): clinical and radiological 
D'Alessandro A, Moraes MAP, Raick AN. Polycystic hydatid disease in Brazil. Report of five new human cases and a short review of other published observations. Revista da Sociedade Brasileira de Medicina Tropical 29:219-228, mai-jun, 1996.

manifestations and treatment with albendazole of a patient from the Brazilian Amazon region. Arquivos de Gastroenterologia de São Paulo 23:177-183, 1986

20. Meneghelli UG, Martinelli ALC, Bellucci AD, Villanova MG. Polycystic hydatid disease (Ecbinococcus vogeli). Treatment with albendazole. Annals of Tropical Medicine and Parasitology 86:152-156, 1992.

21. Meneghelli UG, Martinelli ALC, Llorach Velludo MAS. Cisto de Echinococcus vogeli em fígado de paca (Cuniculus paca) originária do Estado do Acre, Brasil. Revista da Sociedade Brasileira Medicina Tropical 22:153-155, 1990.

22. Meneghelli UG, Martinelli ALC, Llorach Velluto MAS, Bellucci LE, Barbo MLP. Polycystic hydatid disease (Echinococcus vogeli). Clinical, laboratory and morphological findings in nine Brazilian patients. Journal of Hepatology 14:203-210, 1992.

23. O'Grady JP, Yaeger CH, Esra GN, Thomas W. Ultrasonic evaluation of echinococcosis in four lowland gorillas. Journal of American Veterinary Medical Association 181:1348-1350,1982.

24. Pacheco MDK, Leite Pinto RN, Silva Souza LC, Araujo Pereira LI. Doença hidática policística. Relato de um caso procedente do Pará. Revista da Sociedade Brasileira de Medicina Tropical 19(suppl):67,1986.

25. Passos DMM, Pinho Alves M, Creuv O, Freitas G, Matushita JP, Marchiori E. Echinococose alveolar hepática. (Descrição de um caso). Radiologia Brasileira 15:129-132, 1982.

26. Rausch RL, Bernstein JJ. Echinococcus vogeli sp.n. (Cestoda:Taeniidae) fron the bush dog, Speotbos venaticus (Lund) Zeitschrift fur Tropenmedizin und Parasitologie 23:25-34,1972.

27. Rausch RL, D'Alessandro A, Ohbayashi M. The taxonomic status of Echinococcus cruzi Brumpt and Joyeux (Cestoda:Taeniidae) from an agouti (Rodentia: Dasyproctidae) in Brazil. Journal of Parasitology 70:295-302, 1984.

28.Rausch RL, D'Alessandro A, Rausch VR. Characteristics of the larval Echinococcus vogeli Rausch and Bernstein 1972, in the natural intermediate host, the paca, Cuniculus paca $\mathbf{L}$. (Rodentia: Dasyproctidae) The American Journal Tropical Medicine and Hygiene 30:1043-1052, 1981.

29.Rausch RL, Rausch VR, D'Alessandro A. Discrimination of the larval stages of Echinococcus oligartbrus (Diesing, 1863) and E. vogeli Rausch and Bernstein, 1972 (Cestoda: Taeniidae). The American Journal of Tropical Medicine and Hygiene 27:1195-1202, 1978.

30. Timerman A, Andrade DR, Hutzler RU, Marinho IS, Uliana SRB.Terapêutica da hidatidose hepática com albendazole: relato de 1 caso. In: Resumos do IX Congresso Brasileiro de Hepatologia São Paulo, abstract 85, 1986. 